\title{
IMPACT OF DIFFERENT REVEGETATION TECHNIQUES ON SOIL AND PLANT ATTRIBUTES IN A RIPARIAN ZONE ${ }^{1}$
}

\author{
JOÃO MARCOS PEREIRA NOVAIS ${ }^{2}$, FABRÍCIO TOMAZ RAMOS ${ }^{3 *}$, ELIANA FREIRE GASPAR DE CARVALHO \\ DORES $^{4}$, JOÃO CARLOS DE SOUZA MAIA ${ }^{2}$
}

\begin{abstract}
In 2014, the Upper Paraguay River Basin (UPB) plateau in Brazil maintained only 39.5\% of its native vegetation cover, most of which was located in riparian zones that were generally degraded, in legal reserve areas, or in regions without agricultural potential. Due to the lack of practical results in the region, so that farmers could base their projects for the recovery of degraded areas, this work was designed to determine the long-term result of three revegetation techniques and their contributions to soil attributes and vegetative parameters, in the riparian zone of a watershed in the municipality of Campo Verde, located in the UPB. It was found that in only seven years, the technique of distributing a mixture of seeds rich in nitrogen-fixing plant species with washed sand and composted cotton tow, followed by incorporation with light harrowing, favored a rapid establishment of native plants. In this case, the number of species and the floristic diversity was the closest to those of the Tropical Cerrado, i.e., the control. In this technique, Brachiaria brizantha was not dominant, and the mean of total organic carbon storage in the soil ( $\mathrm{T}_{\mathrm{OCS}}$ ) was significantly lower, thereby indicating that riparian zones with higher $\mathrm{T}_{\mathrm{OCS}}$ do not necessarily have greater plant diversity. Therefore, the competition caused by $B$. brizantha can affect ecological diversity in areas undergoing ecological succession.
\end{abstract}

Keywords: Cerrado biome. Riparian forest. Riparian vegetation.

\section{IMPACTO DE DIFERENTES TÉCNICAS DE REVEGETAÇÃO NOS ATRIBUTOS DO SOLO E DAS PLANTAS EM UMA ZONA RIPÁRIA}

RESUMO - Em 2014, o planalto da Bacia Hidrográfica do Alto Paraguai (BAP), Brasil, mantinha apenas $39,5 \%$ da sua cobertura vegetal nativa, em sua maioria, localizada em zonas ripárias, em geral, degradadas, em áreas de reserva legal ou em regiões sem aptidão agropecuária. Devido a carência de resultados práticos na região, de modo que os agropecuaristas pudessem embasar os projetos de recuperação de áreas degradadas, objetivou-se nesse trabalho determinar o resultado a longo prazo de três técnicas de revegetação implantados em uma zona ripária e suas contribuições sobre atributos do solo e parâmetros vegetativos, numa microbacia do município de Campo Verde, localizada na BAP. Verificou-se que, em apenas sete anos, a técnica de distribuição a lanço de uma mistura de sementes rica em espécies de plantas fixadoras de nitrogênio, com areia lavada e estopa de algodão compostada, seguida da incorporação com gradagem leve favoreceu um rápido estabelecimento das plantas. Nesse caso, o número de espécies e a diversidade florística se aproximaram aos do Cerradão Tropical, testemunha. Na técnica em que ocorreu a dominância de Brachiaria brizantha, o valor médio de estocagem de carbono total no solo $\left(\mathrm{E}_{\mathrm{COT}}\right)$ foi significativamente maior, inferindo que zonas ripárias com maior $\mathrm{E}_{\mathrm{CO}}$ não indicam maior diversidade de plantas. Portanto, a competição provocada pela $B$. brizantha pode afetar a diversidade ecológica nas áreas em processo de sucessão ecológica.

Palavras-chave: Bioma cerrado. Mata ciliar. Vegetação ripícola.

\footnotetext{
${ }^{*}$ Corresponding author

${ }^{1}$ Received for publication in 07/01/2019; accepted in 12/06/2019.

Paper extracted from the dissertation of the first author.

${ }^{2}$ Graduate Program in Tropical Agriculture, Universidade Federal de Mato Grosso, Cuiabá, MT, Brazil; marcosfertsolos@gmail.com ORCID: 0000-0002-3868-110X, jotace@terra.com.br - ORCID: 0000-0001-6204-8112.

${ }^{3}$ Empresa Mato-grossense de Pesquisa, Assistência e Extensão Rural, Cuiabá, MT, Brazil; fabriciotomazramos@gmail.com - ORCID: 0000 $-0002-0724-0133$.

${ }^{4}$ Graduate Program in Water Resources, Universidade Federal de Mato Grosso, Cuiabá, MT, Brazil; elidores@gmail.com - ORCID: 00000001-5175-3537.
} 


\section{INTRODUCTION}

The São Lourenço River is one of the watercourses that contributes to the formation of the Upper Paraguay River Basin (UPB). This basin is divided into the plateau, where the municipality of Campo Verde is located, and the plain, which forms the Pantanal. The UPB makes up $4.3 \%$ of the Brazilian territory and is spread across the states of Mato Grosso do Sul (51.8\%) and Mato Grosso (48.2\%). However, it was found that in 2014, while the Pantanal plain kept $85.1 \%$ of its native vegetation, the plateau maintained only $39.5 \%$, because a large part of the area had been converted into agricultural and pastoral land, limiting the Cerrado biome to degraded riparian zones, legal reserves, or regions without agricultural potential (NOMOTO et al., 2015).

Riparian areas are vegetated areas that surround intermittent or perennial watercourses. Their conservation minimizes damage to water resources by stabilizing slopes, from springs to the mouth of a river basin (PERT et al., 2010). In addition, riparian zones are important in preventing biodiversity loss by forming ecological corridors (BURKHARD; PETROSILLO; COSTANZA, 2010; ATTANASIO et al., 2012). In this sense, carrying out agricultural activities without ensuring the protection of riparian zones can result in environmental effects that are acute and complex to measure. Therefore, according to Wantzen et al. (2012), it is necessary to promote and discuss, in conjunction with the local rural community, the importance of riparian zone conservation for the environment.

The restoration of riparian zones, when the isolation of the area and natural regeneration (especially in sandy and degraded soils) is taken into account, is very slow (ATTANASIO et al., 2012; XIA et al., 2018). In addition, competition by Brachiaria sp. can make regeneration even more difficult, as it limits ecological succession (DURIGAN et al., 1998; BELAN; PIRES; NASCIMENTO, 2018). Thus, the soil must be able to sustain plant growth to allow the riparian zone to regenerate. Therefore, one of the ways to hypothetically verify regeneration is by determining the total soil organic carbon stock ( $\left.\mathrm{T}_{\mathrm{OCS}}\right)$, as according to Ramos et al. (2018), the $\mathrm{T}_{\mathrm{OCS}}$ is strongly and significantly correlated with several physical and chemical soil attributes that facilitate the development of plants.

For this reason, selecting revegetation techniques that can accelerate the recovery of riparian zones, favor the increase of $\mathrm{T}_{\mathrm{OCS}}$, and increase the speed of succession of native species of the biome itself, instead of fallow land, is a challenge. Thus, the objective of this research was to determine the efficiency of three revegetation techniques and their contribution to soil and vegetation attributes, when implemented in a riparian zone in a micro watershed of the municipality of Campo Verde.

\section{MATERIAL AND METHODS}

The study was conducted in the municipality of Campo Verde, Mato Grosso, Brazil. The climate of the region is "Aw" according to the KöppenGeiger climate classification, with a rainy season from October to April and a dry period from May to September (ALVARES et al., 2014). The average annual rainfall is $1750 \mathrm{~mm}$, the average annual temperature is $24{ }^{\circ} \mathrm{C}$, and the region has an average altitude of $736 \mathrm{~m}$. In the municipality, a watershed of the São Lourenço River was selected. The native vegetation along the riparian zone was minimal in June 2005, with anthropic use occurring along an existing dam in the area (Figure 1D). According to Checoli (2012), the restoration of this area (from the spring to the mouth of the river) began during the rainy season in December 2010, and in 2017 it was possible to observe the restored area of the riparian vegetation using to an image taken in 2017 (Figure $1 F)$.

The history of the treatment sites and the methodology carried out by Checoli (2012) during the application of these reforestation techniques in conjunction with the local community are detailed below (Figure 1F).

T0 - Area with native vegetation of the Cerrado: No history of anthropic use, and taken as the control. On the day of sampling, the soil had a thick layer of plant litter of almost $10 \mathrm{~cm}$ and a large number of fine roots in the first few centimeters of soil. The local vegetation was characterized as Tropical Subevergreen Cerrado, with trees ranging from 6 to $15 \mathrm{~m}$ in height;

T1 - Seeds distributed by hand and incorporated into the soil: This treatment was used in an area where the native Cerrado was deforested in 1982, and Brachiaria brizantha was cultivated until August 1998. From October 1998 until 2010, the land was cultivated with a succession of soybean/ maize and soybean/cotton. In September 2010, an adjacent area of 0.75 hectares was demarcated and the soil was decompressed to a depth of $50 \mathrm{~cm}$, using a three-rod hydraulic subsoiler. Then, a limestone application machine was used to distribute the seeds of native Cerrado species at a density of $23 \mathrm{~kg} \mathrm{ha}^{-1}$ (Table 1). This quantity of seeds, i.e., $23 \mathrm{~kg}$, was mixed with $23 \mathrm{~kg}$ of washed sand and $23 \mathrm{~kg}$ of composted cotton tow. This mixture was distributed onto the soil and then incorporated with a leveling grid; 


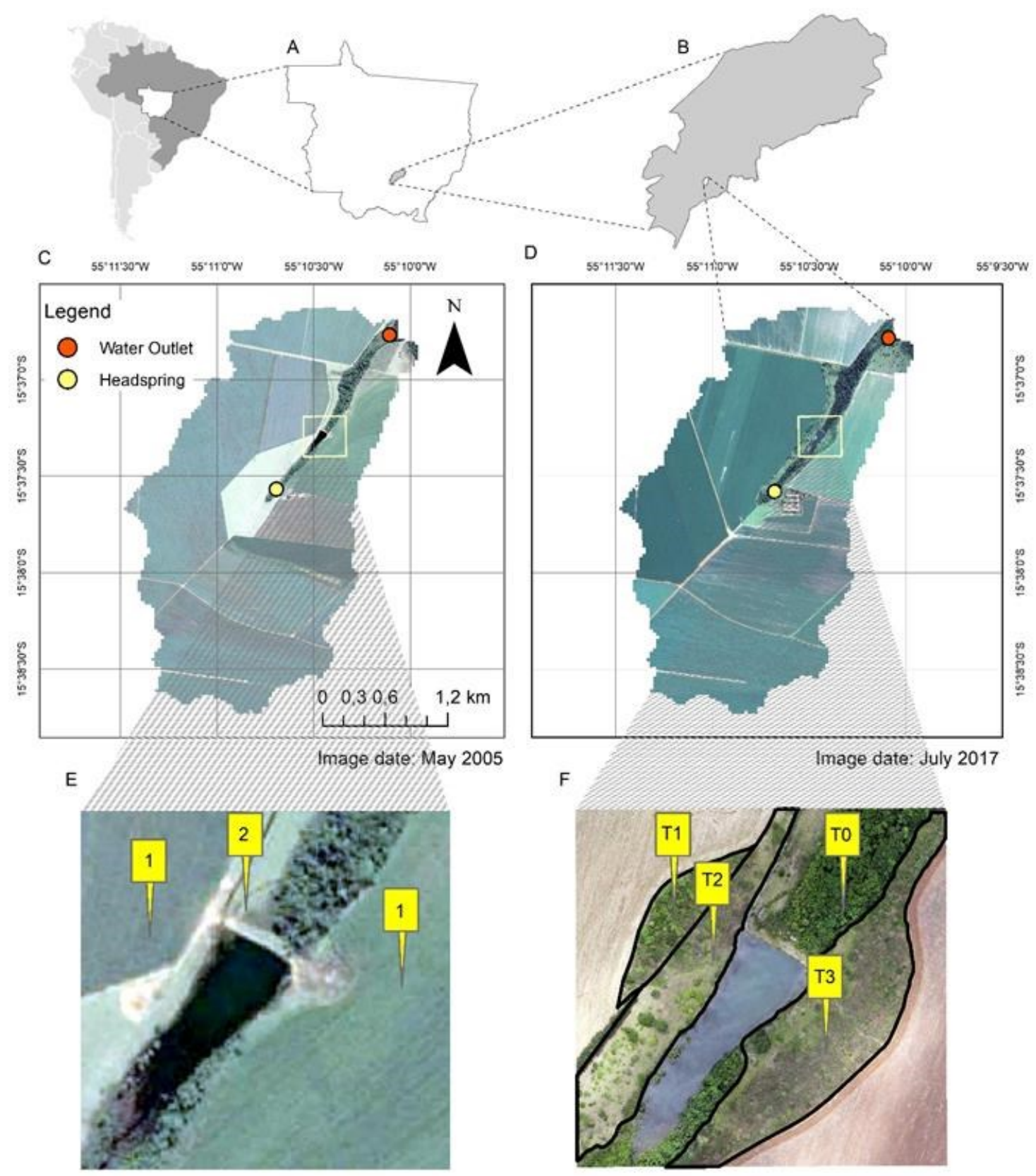

Figure 1. (A) State of Mato Grosso; (B) Municipality of Campo Verde; (C) Satellite image from 2005 of the São Lourenço River watershed, where (E) a zoom around the dam, being 1: cotton crop, 2: pasture; (D) Image of 2017, being (F) an clipping around the dam, where the reforestation techniques "T1, T2, and T3" and the native Cerrado area "T0" are indicated. Note: Google Earth georeferenced images with SIRGAS 2000 Zone 21S projection.

T2 - Set-aside land followed by the planting of seedlings: Differing from the technique (T1), in this treatment, the area used was a pasture that was maintained until 2005. In September of the same year, the process of reforestation began, from the west of the spring (Figure 1F) to near the mouth of the river, where the random planting of native Cerrado seedlings was carried out (Table 2). With a spacing of $5 \times 5 \mathrm{~m}$, the planting was carried out in pits a depth of $0.40 \mathrm{~m}$, made with a hydraulic perforator coupled to a tractor. Prior to the planting of the seedlings, $100 \mathrm{~g}$ of dolomitic limestone and mineral fertilizer (NPK 4-14-8) were added.
However, B. brizantha was not eliminated from the area, and only weeding around the seedlings was carried out in the first year after planting.

T3 - Sowing with a combination of seed mixtures and planting of seedlings: The history of this area is the same as in (T1), but the soil in T3 was decompacted using a three-stem hydraulic subsoiler with a working depth of $0.50 \mathrm{~m}$. In this treatment, the seeds were distributed in rows, using a tractor with a power of $140 \mathrm{hp}$, coupled to a pneumatic seeder of 12 rows spaced $0.50 \mathrm{~m}$ apart. The sowing machine had 12 boxes for seeds and 6 for fertilizer. In the odd-numbered lines of the sowing boxes, a 
mixture of three native species of the Cerrado was added $(5.6 \mathrm{~kg}$ of Cajanus cajan; $0.6 \mathrm{~kg}$ Plathypodium elegans; $0.2 \mathrm{~kg}$ of Copaifera langsdorffii), depositing 7 seeds per meter. In evennumbered lines, the fertilizer box was used for sowing $84.45 \mathrm{~kg}$ of seeds of native Cerrado species (Table 1). In the visible rows of the furrows left by the subsoiler, the planting of seedlings of different species was carried out, at a spacing of $5 \times 5 \mathrm{~m}$.

Table 1. Seeds and seedlings of native species used in restoration techniques.

\begin{tabular}{|c|c|c|c|}
\hline \multicolumn{2}{|l|}{ Seeds $^{1}$} & \multicolumn{2}{|c|}{ Seedlings $^{2}$} \\
\hline Species & Quantity (kg) & Species & Quantity. (seedlings) \\
\hline Anacardium nanum & 2.70 & Anadenanthera macrocarpa & 50 \\
\hline Anadenanthera macrocarpa & 0.60 & Buchenavia capitata & 20 \\
\hline Apeiba bourboun & 0.20 & Cariniana rubra & 50 \\
\hline Bauhinia sp. & 0.60 & Ceiba erianthos & 20 \\
\hline Buchenavia capitata & 1.40 & Colubrina glandulosa & 70 \\
\hline Cajanus cajan & 17.0 & Enterolobium contortisiliquum & 50 \\
\hline Canavalia ensiformis & 64.0 & Ficus catappifolia & 30 \\
\hline Cecropia sp. & 0.20 & Genipa americana & 30 \\
\hline Copaifera langsdorffii & 0.60 & Inga edulis & 120 \\
\hline Dimorphandra mollis & 0.60 & Inga marginata & 100 \\
\hline Dipteryx alata & 2.00 & Myracrodruon urundeuva & 120 \\
\hline Enterolobium contortisiliquum & 1.35 & Psidium guajava & 100 \\
\hline Enterolobium schomburgkii & 0.35 & Spondia dulcis & 60 \\
\hline Guazuma ulmifolia & 0.20 & Sterculia chicha & 50 \\
\hline Jacaranda micrantha & 0.13 & Tabebuia alba & 80 \\
\hline Machaerium $s p$ & 0.60 & Tabebuia aurea & 200 \\
\hline Myracrodruon urundeuva & 0.35 & Tabebuia spp & 200 \\
\hline Peltogyne confertiflora & 0.60 & Tamarindus indica & 100 \\
\hline Platypodium elegans & 2.00 & Tilisiae suculenta & 30 \\
\hline Plathymenia reticulata & 0.60 & & \\
\hline Samanea saman & 0.30 & & \\
\hline Sclerolobium paniculatum & 0.35 & & \\
\hline Solanum excelsum & 1.35 & & \\
\hline Sterculia chicha & 3.00 & & \\
\hline Terminalia argentea & 0.60 & & \\
\hline
\end{tabular}

Source: Checoli (2012).

In order to compare the different recovery techniques used, the soil profile was sampled and described in the central region of each study area (T0, T1, T2 and T3) in October 2017 (Figure 1F). The morphological characteristics of the profiles were described up to $2 \mathrm{~m}$ in depth as described in Santos et al. (2015), and the soil was classified according to the "Brazilian Soil Classification System - SiBCS" and the SiBCS was matched with the classification system "World Reference Base for Soil Resources" (WBR/FAO) and the "Soil Taxonomy" (SANTOS et al., 2018).

From each soil profile, five simple deformed and undeformed soil samples were collected for each horizon. The undeformed samples were collected with a "Kopeck" sampler and a stainless-steel cylinder (50 $\mathrm{mm}$ in diameter and $50 \mathrm{~mm}$ in height) to determine the soil density. The samples were used for the determination of the exchangeable $\mathrm{K}$ content, extracted with $\mathrm{HCl}$ solution of $0.05 \mathrm{~mol} \mathrm{~L}^{-1}$ and $\mathrm{H}_{2} \mathrm{SO}_{4} 0.025 \mathrm{~mol} \mathrm{~L}^{-1}$ (Mehlich-1); exchangeable Ca, $\mathrm{Mg}$ and $\mathrm{Al}$ content, extracted with $\mathrm{KCl}$ solution $1 \mathrm{~mol} \mathrm{~L}^{-1}$; and the $\mathrm{H}$ and $\mathrm{Al}$ contents, extracted with calcium acetate solution at $\mathrm{pH}=7.0$. The amount of gravel and the soil texture were determined by the difference in the mass of the particles; and the total organic carbon content was determined using wet combustion in a solution of potassium dichromate in an acid medium, with the addition of sulfuric acid and heating in a digester block, the excess of potassium dichromate being titrated with ammonium ferrous sulfate, using "ferroin" as an indicator (TEIXEIRA et al., 2017). These data were also used for soil classification (SANTOS et al., 2018).

In order to determine the total organic carbon stock $\left(\mathrm{T}_{\mathrm{OCS}}\right)$ along the soil profile, the sampling was carried out according to the basic recommendations of the Intergovernmental Panel on Climate Change (IPCC, 2006), which recommends the individualization of homogeneous areas, with stratified collection at a minimum depth of $0.30 \mathrm{~m}$. $\mathrm{T}_{\text {OCS }}$ calculations were performed according to Ramos et al. (2018), but for the present study, the gravel content was discounted to avoid errors that could cause the overestimation of $\mathrm{T}_{\mathrm{OCS}}$, as the gravel is chemically inert, and is heavier than sand, silt, and clay particles.

The identification of tree species around the soil profile of each of the areas studied (Figure 1F) was performed according to Lorenzi (2009). The 
total sampled area was $900 \mathrm{~m}^{2}$, i.e., $30 \times 30 \mathrm{~m}$. With this information, the following was calculated according to Clarke and Warwick (2001): the density of species, which indicates the number of species per area; the dominance index, which expresses the relationship between the number of individuals of a given species and the number of individuals of all found species; the accumulated curves of abundance and dry biomass, in which the species were ordered in terms of increasing abundance (perennials, semiperennials and annuals); and the Pielou index, which indicates the equability, measured based on the estimate of diversity of the Shannon index.

For the determination of biomass curves, the estimation of dry biomass of tree plants was performed using the recommended allometric equation for Cerrado plants (MIGUEL et al., 2017). The estimation of the dry biomass of Brachiaria sp was performed after cutting the plants at ground level and subsequently drying them at $60{ }^{\circ} \mathrm{C}$ for $72 \mathrm{~h}$ (RIBEIRO et al., 2012). This sampling was performed within a square of $1 \mathrm{~m}^{2}$, repeated four times at random within the $900 \mathrm{~m}^{2}$ study site (treatment) (Figure 1F).

The normal distribution of data was evaluated by the Shapiro-Wilk test $(\mathrm{p}>0.05)$. The observed $\mathrm{T}_{\mathrm{OCS}}$ data were subjected to an analysis of variance using the $F$ test at the level of $5 \%$ probability of error, and the mean values were compared by Tukey's test $(\mathrm{p}<0.05)$.

\section{RESULTS AND DISCUSSION}

The four soil profiles analyzed were framed in the loam-clay texture class $(50.65 \pm 6.86 \%$ clay $)$, except for horizons $\mathrm{A}$ and $\mathrm{C} 1$ of the Fluvent Entisol, which presented free texture $(31.10 \pm 4.80 \%$ clay $)$ in the area under native vegetation of the Cerrado (Figure 2A). In addition, different from the typical morphological characteristics of oxisols, according to Santos et al. (2018), such as little particle size variation in the profile verified using T1 and T2 techniques, in the profile from T0 and T3 techniques there was preponderance of other diagnostic characteristics, that is, fluvent and plinthite, which made the soils of these sites fall into two other classes. Thus, the soil in T0 was probably formed by water erosion of varying degrees of intensity, due to the erratic amount of gravel deposited in an alluvialcolluvial way. In the soil from T3, a diagnostic occurrence of plinthite from $0.30 \mathrm{~m}$ depth was observed, suggesting previous oscillations of the groundwater table closer to the surface (Figure 2).
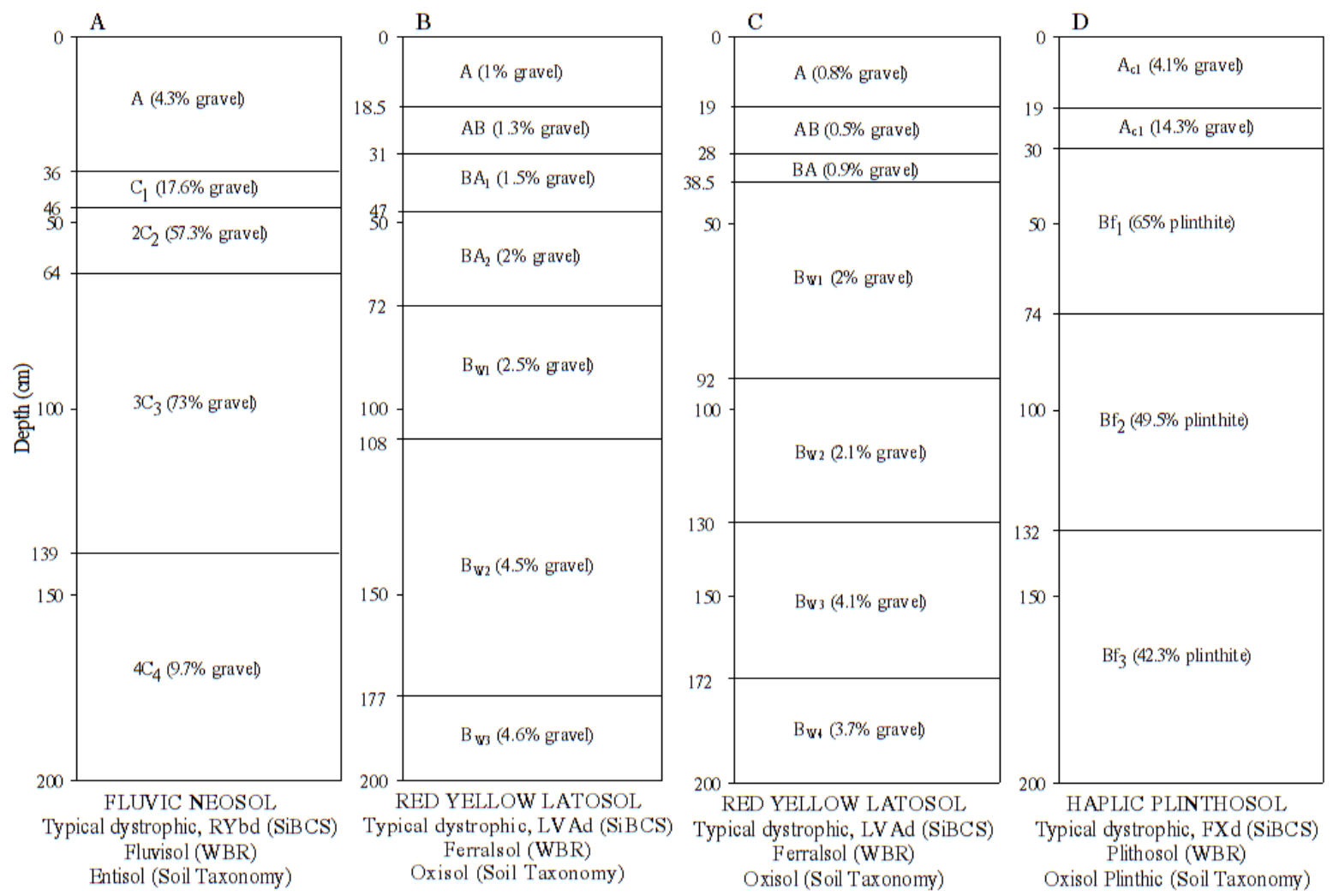

Figure 2. Percentage of gravel and plinthite and soil classification in the four areas: (A) T0 - Area under native vegetation of the Cerrado; (B) T1 - Seeds distributed by hand and incorporated into the soil; (C) T2 - Set-aside land followed by planting of seedlings; (D) T3 - Sowing with combination of seed mixtures and planting of seedlings. 
Based on the morphological description of the soil profiles, it was found that the horizons analyzed were probably influenced over time by the development of vegetation and by the effect of anthropic action, because the thickness of the soil surface horizon under native vegetation of the Cerrado (Figure 2A) was practically double when compared to the treatments T1, T2 and T3 (Figure 2 ). In this sense, it is possible that with the removal of the native vegetation of these three treatment sites for a long period, there was a reduction in soil organic matter. In addition, unlike the profiles described in $\mathrm{T} 2$ and $\mathrm{T} 3$, in $\mathrm{T} 1$, the influence of the transitional morphological characteristics of horizon A extended to $0.72 \mathrm{~m}$ depth (Figure 2B). Thus, it is inferred that the revegetation technique used in this area (T1) favored the development of morphological characteristics, such as greyish coloration and granular soil structure, typical of horizon A and its transitions. According to Santos et al. (2013), this is due to the deepening of organic matter along the soil profile, whose effect is manifested by horizon A and its transitions in depth, as compared to other treatments (Figure 2B).

It is important to note that because it is an evaluation in a natural environment, and because the soil profile texture in the T0 area in the first $0.30 \mathrm{~m}$ depth was loamy, and the others fit into the loamyclay (as observed in Figure 2), a corrective estimate of the $\mathrm{T}_{\mathrm{OCS}}$ was performed if the soil under $\mathrm{T} 0$ presented loamy-clay texture. This estimate was performed using a statistical model for the application of variance analysis, that is, $\mathrm{T}_{\mathrm{OCS}}$ $\left(\mathrm{Mg} \mathrm{ha}^{-1}\right)=4.7881+0.022 \times \mathrm{E}_{\mathrm{CLAY}}(\mathrm{r}=0.81 ; \mathrm{R} 2=$ $0.64 ; \mathrm{P}=0.004)$, with $\mathrm{E}_{\mathrm{CLAY}}$ equal to the clay stock in $\mathrm{Mg} \mathrm{ha}^{-1}$, that is, corrected with the current soil density value. Then, from the identification of tree species around the soil profile, some vegetative parameters were determined (Table 2).

Table 2. Total organic carbon storage $\left(\mathrm{T}_{\mathrm{OCS}}\right)$ and estimated vegetative parameters in each technique of vegetative restoration in the riparian zone.

\begin{tabular}{lcccccc}
\hline Treatment & $\begin{array}{c}\mathrm{T}_{\mathrm{OCS}} \\
\left(\mathrm{Mg} \mathrm{ha}^{-1}\right)\end{array}$ & $\begin{array}{c}\text { Number } \\
\text { of plants }\end{array}$ & $\begin{array}{c}\text { Number of } \\
\text { species }\end{array}$ & $\begin{array}{c}\text { Density } \\
\text { of } \\
\text { species }\end{array}$ & $\begin{array}{c}\text { Shannon Index } \\
\left(\mathrm{H}^{\prime}\right)\end{array}$ & $\begin{array}{c}\text { Pielou Index } \\
\left(\mathrm{J}^{\prime}\right)\end{array}$ \\
\hline T0 & $65,4 \mathrm{a}^{*}$ & 43 & 15 & 0,0166 & 2,4632 & 0,9095 \\
$\mathrm{~T} 1$ & $74,5 \mathrm{a}$ & 108 & 14 & 0,0155 & 2,0736 & 0,7857 \\
$\mathrm{~T} 2$ & $114,1 \mathrm{~b}$ & 13534 & 13 & 0,0144 & 0,0200 & 0,0078 \\
$\mathrm{~T} 3$ & $100,8 \mathrm{~b}$ & 4532 & 11 & 0,0122 & 0,0555 & 0,0231 \\
\hline
\end{tabular}

*mean values followed by the same letter do not differ statistically (Tukey's test; $p<0.05$; CV $(\%)=19.59)$.

The control area (T0) had the highest uniformity in relation to the abundance of species $\left(\mathrm{H}^{\prime}=2.46\right)$, followed by $\mathrm{T} 1\left(\mathrm{H}^{\prime}=2.07\right)$. In $\mathrm{T} 2$ and $\mathrm{T} 3$, uniformity was considered low, although the number of species sampled in the area varied little among all reforestation techniques. This happened due to discrepancies in the number of individuals per species, in this case in the number of $B$. brizantha (Table 2). In addition, it is possible that this dominant presence of $B$. brizantha resulted in the highest value of $\mathrm{T}_{\mathrm{OCS}}$ observed, in the first $0.30 \mathrm{~m}$ of the T2-area profile, and that it did not differ statistically from the T3 technique. On the other hand, the $\mathrm{T} 0$ and $\mathrm{T} 1$ techniques did not differ significantly from each other, but both stored less carbon than T2 and T3. This pattern of greater carbon accumulation in areas with grasses was also observed in other studies. For example, when Araújo et al. (2011) evaluated the impact of converting forest into pasture and compared native forest with pastures of 3, 10 and 20 years, they observed that areas with pasture stored more carbon in the surface layers when compared with native vegetation. The authors attributed this result to the fact that pasture consists of grasses with $\mathrm{C} 4$ metabolism, that is, plants more efficient in assimilating $\mathrm{CO}_{2(\mathrm{~g})}$. In addition, they have fasciculate roots and a larger volume of thin roots produced in the first $0.30 \mathrm{~m}$ depth, which increases the area of contact with the soil. However, in a native forest, the increase in carbon mainly comes from leaves, branches and trunks, with different levels of decomposition and depositing onto the soil surface.

Furthermore, according to Denardin et al. (2014), in comparison of the areas of native vegetation, in pastures, which have thin, fasciculate roots with a large volume, most of the carbon is stored in the soil, in the form of the root system, alive or decomposing, concentrating about $40 \%$ to $50 \%$ of the carbon stock in the first $0.30 \mathrm{~m}$ of depth. Considering the original assumptions, soil with a greater carbon stock does not necessarily correspond with greater plant diversity. A similar result was found by Ferreira et al. (2018) when evaluating different environments. They concluded that conservation strategies focused only on carbon storage may not result in the protection of biodiversity. Thus, the $\mathrm{T}_{\mathrm{OCS}}$ values verified in $\mathrm{T} 0$ and $\mathrm{T} 1$ techniques that are significantly lower than in $\mathrm{T} 2$ and T3, confirm that greater carbon storage may not be accompanied by greater plant diversity. Given this, Ferreira et al. (2018) clarify that there may be a 
positive correlation between $\mathrm{T}_{\mathrm{OCS}}$ and biodiversity in severely degraded forests, but this proportional relationship is lost as the process of ecological succession happens in the absence of B. brizantha. Therefore, carbon stock studies should consider the biodiversity around the assessed area to justify the protection of native or recovering forests.

Additionally, it was found that the presence of $B$. brizantha on $\mathrm{T} 2$ and $\mathrm{T} 3$ interfered with the indices of floristic diversity, due to a greater discrepancy in relation to the reference area, which showed greater uniformity in terms of floristic composition $\left(\mathrm{J}^{\prime}=0.90\right)$, followed by $\mathrm{T} 1\left(\mathrm{~J}^{\prime}=0.78\right)$ (Table 2). Therefore, the presence of $B$. brizantha

A

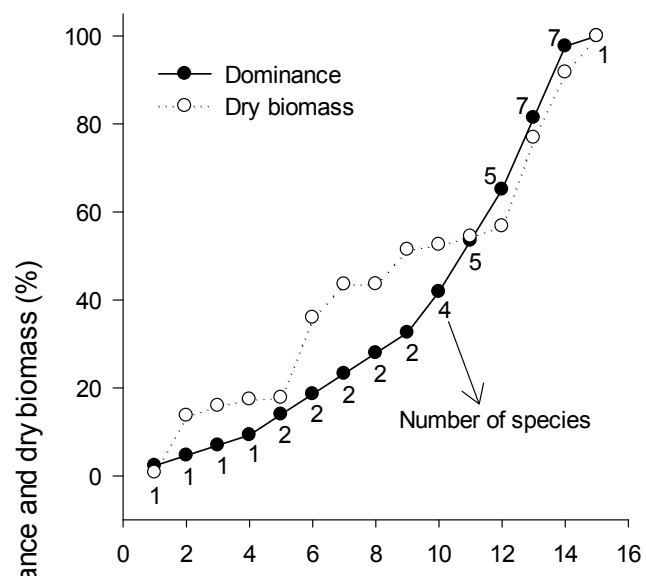

C

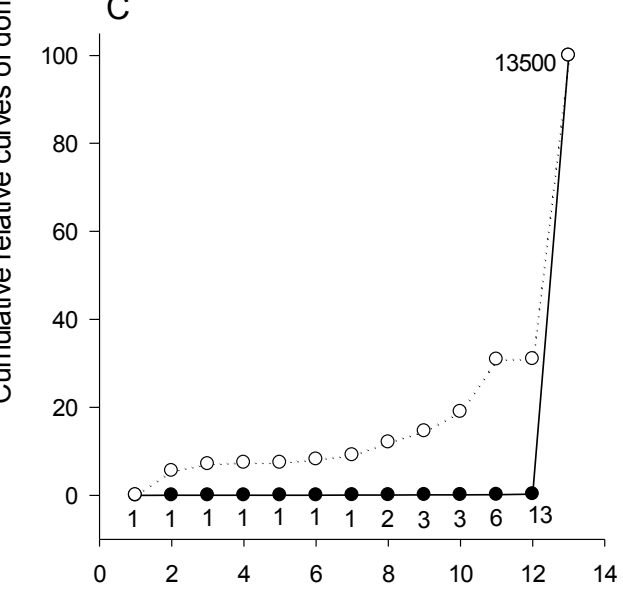

interfered in the development of native species from the Cerrado, causing reduction of the Pielou Index of $\mathrm{T} 2$ and $\mathrm{T} 3$ reforestations. This influence of $B$. brizantha on the vegetative parameters can be better understood from the determination of the biomass curves, in which the estimation of the dry biomass of the plants in each area was performed. In this sense, the dominance and biomass curves of the sampled plant species in each environment show that the greatest dominance of native species occurred in T0 and $\mathrm{T} 1$, free from the presence of $B$. brizantha (Figure 3A; 3B). In T2 and T3, the dominance of $B$. brizantha became an obstacle for the development of other plants (Figure 3C; 3D).
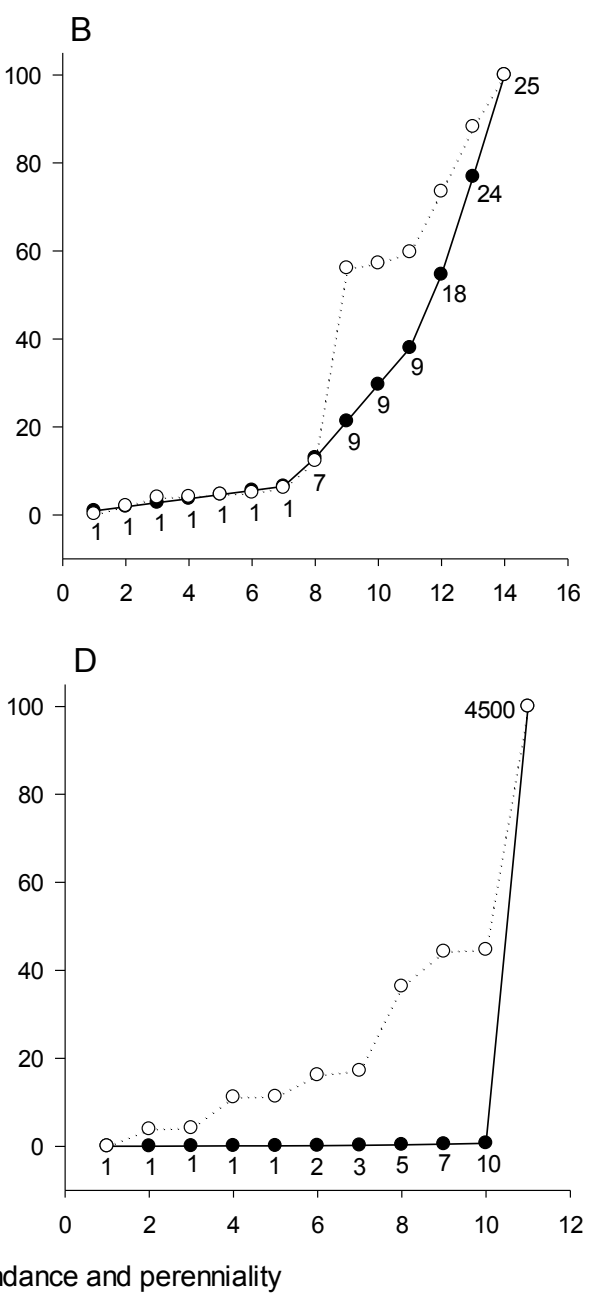

Figure 3. Vegetative parameters observed in the studied areas. Note: The superscript number below represents the species rank: (A) $\mathrm{T}_{0}$ - Tropical Sub-evergreen Cerrado (Eriotheca gracelipes ${ }^{1}$, Copaifera langsdorffii ${ }^{2}$, Xylopia aromatica $^{3}$, Pouteria ramiflora ${ }^{4}$, Calophyllum brasiliensis ${ }^{5}$, Simarouba versicolor ${ }^{6}$, Platypodium elegans $^{7}$, Cupania guianensis $^{8}$, Ocotea spisciana ${ }^{9}$, Protea $s .^{10}{ }^{10}$, Casearia sylvestris ${ }^{11}$, Trichilia catigua ${ }^{12}$, Scherolobium sp ${ }^{13}$., Vismia brasiliensis ${ }^{14}$, Cecropia $s p .^{15}$ ); (B) $\mathrm{T}_{1}=$ seed mixture with incorporation (Jacaranda brasiliensis ${ }^{1}$, Maclura tintoria ${ }^{2}$, Combretum leprosum ${ }^{3}$, Alibertia edulis ${ }^{4}$, Anacardium nanum $^{5}$, Tabebuia sp. ${ }^{6}$, Cecropia hololeuca ${ }^{7}$, Anadenanthera sp. ${ }^{8}$, Guazuma ulmifolia ${ }^{9}$, Myracrodruon urundeuva ${ }^{10}$, Sterculia striata ${ }^{11}$, Bauhinia rufa ${ }^{12}$, Albizia lebbeck ${ }^{13}$, Simarouba versicolor $\left.{ }^{14}\right) ;(\mathrm{C}) \mathrm{T}_{2}-\mathrm{Set}$ aside land and seedling planting (Trema $s p^{1}$, Cariniana $s p^{2}$, Myracrodruon urundeuva ${ }^{3}$, Psidium sp ${ }^{4}$, Calophyllum brasiliensis ${ }^{5}$, Inga sp. ${ }^{6}$, Guazuma ulmifolia ${ }^{7}$, Genipa americana ${ }^{8}$, Enterolobium $s p^{9}$, Tabebuia sp. ${ }^{10}$, Anadenanthera sp. ${ }^{11}$, Simarouba versicolor ${ }^{12}$, Brachiaria brizantha ${ }^{13}$ ); (D) $\mathrm{T}_{3}$ - sowing of seed mixture and planting of seedlings (Anacardium nanum $^{1}$, Trema $s^{2}$, Tabebuia sp. ${ }^{3}$, Albizia lebbeck, Simarouba versicolor ${ }^{5}$, Bauhinia rufa ${ }^{6}$, Myracrodruon urundeuva ${ }^{7}$, Anadenanthera sp. $^{8}$, Sterculia striata ${ }^{9}$, Cajanus cajan ${ }^{10}$, Brachiaria brizantha ${ }^{11}$ ). 
With regards to biomass production, in the control area (T0), there were some species with little dominance, but with the capacity to accumulate about $40 \%$ of the dry biomass, considering that it is an area with already established perennial species (Figure 3A). In T1, because these plants are still in the process of ecological succession, the dry biomass was related to the species with greater dominance (Figure 3B). Regarding the T2 and T3 techniques, a similarity was observed in the accumulated biomass curves (Figure 3C, 3D), as more than $50 \%$ of the biomass corresponded to $B$. brizantha.

In view of this, Durigan et al. (1999) and Belan; Pires and Nascimento (2018) indicate that the biomass produced by $B$. brizantha may interfere with the development of some native species, especially those whose seeds need luminosity to germinate and develop. Therefore, planting seedlings of native forest species in areas with a dominant presence of $B$. brizantha is not a recommended technique because it interferes with the speed of ecological succession. In these cases, according to Durigan et al. (1999), selective herbicide control is a feasible alternative. These authors observed an increase of $20 \%$ in the density of species and $48 \%$ in the coverage by native species in an area without forage grass control. In addition, a negative correlation has been found between the dominance of grasses and abundance and richness of native species, caused by high competition for luminosity, water and nutrients (VIDRA; SHEAR; STUCKY, 2007; MANTOANI et al., 2012; SIMMONS et al., 2016). In view of this, it is inferred that with the removal of grasses, the germination and survival rates of native species will, according to Chazdon (2012) and Fragoso et al. (2017), likely increase and reduce the time taken for ecological succession.

\section{CONCLUSION}

The revegetation technique (T1), based on the distribution by hand of a mixture of seeds rich in species of nitrogen-fixing plants, with washed sand and composted cotton tow followed by incorporation with light harrowing, was the one that best contributed to the establishment and development of the plants, as the number of species and floristic diversity were closest to those of the Tropical Cerrado, which is the control area. In addition, due to the rapid establishment arboreal in T1, this prevented the competitive establishment of Brachiaria brizantha that was observed in other techniques, where there was a delay in the process of succession and tree establishment, and the treatment areas required some maintenance, such as harvesting weeds near the seedlings. Therefore, T1 is the recommended technique for recovery of Permanent Preservation Areas (PPA) and Legal Reserves in similar soil and climatic conditions.
Regarding the contributions of revegetation techniques on soil attributes, it was found that the evaluation of total organic carbon storage $\left(\mathrm{T}_{\mathrm{OCS}}\right)$ should not be performed without considering the vegetative parameters in the surrounding area, because the highest $\mathrm{T}_{\mathrm{OCS}}$ values were found in $\mathrm{T} 2$ and T3 techniques, where there was dominance of $B$. brizantha. Therefore, conservation strategies focused solely on carbon storage may not result in the protection of biodiversity.

\section{ACKNOWLEGMENTS}

We thank CNPq (National Council on Research and Development - Brazil) for the financial support (Project number 403802/2013-0) of this research.

\section{REFERENCES}

ALVARES, C. A. et al. Köppen's climate classification map for Brazil. Meteorologische Zeitschrift, 22: 711-728, 2013.

ARAÚJO, E. A. et al. Impacto da conversão florestapastagem nos estoques e na dinâmica do carbono e substancias húmicas do solo no bioma Amazônico. Acta amazônica, 41: 103-114, 2011.

ATTANASIO, C. M. et al. P. A importância das áreas ripárias para a sustentabilidade hidrológica do uso da terra em microbacias hidrográficas. Bragantia, 71: 493-501, 2012.

BELAN, H. C.; PIRES, M. S.; NASCIMENTO, A. R. T. Regeneração lenhosa em pastagem abandonada em área de floresta estacional decidual. Neotropical Biology and Conservation, 13: 224-234, 2018.

BURKHARD, B.; PETROSILLO, I.; COSTANZA, R. Ecosystem services - bridging ecology,economy and social sciences. Ecological Complexity, 7: 257 $259,2010$.

CHAZDON, R. Regeneração de florestas tropicais. Boletim do Museu Paraense Emílio Goeldi Ciências Naturais, 7: 195-218, 2012.

CHECOLI, C. H. B. Plano de recuperação de áreas degradadas de trechos da cabeceira do rio São Lourenço, Campo Verde - MT, mediante diagnóstico rural participativo. 2012. $82 \mathrm{f}$. Dissertação (Mestrado em Recursos Hídricos: Área de Concentração em Manejo e Conservação) Universidade Federal do Mato Grosso, Cuiabá, 2012.

CLARKE K. R.; WARWICK, R, M. Change in 
Marine Communities: An Approach to Statistical Analysis and Interpretation. $2^{\mathrm{a}}$. ed. Plymouth: United Kingdon, 2001. 176 p.

DENARDIN, N. et al. Estoque de carbono no solo sob diferentes formações florestais, Chapecó - SC. Ciência Florestal, 24: 59-69, 2014.

DURIGAN, G. et al. Indução do processo de regeneração da vegetação de cerrado em área de pastagem. Acta Botanica Brasilica, 12: 421-429, 1998.

FERREIRA, J. et al. Carbon-focused conservation may fail to protect the most biodiverse tropical forests. Nature Climate Change, 8: 744-749, 2018.

FRAGOSO, R. O. et al. Barreiras ao estabelecimento da regeneração natural em áreas de pastagens abandonadas. Ciência Florestal, 27: 1451-1464, 2017.

IUSS Working Group WRB. World Reference Base for Soil Resources 2014. International soil classification system for naming soils and creating legends for soil maps. Rome: FAO, 2015. 192 p.

LORENZI, H. Árvores brasileiras: manual de identificação e cultivo de plantas arbóreas nativas do Brasil. $3^{\text {a }}$ ed. Nova Odessa: Instituto Plantarum, 2009. 384 p.

MANTOANI, M. C. et al. Efeitos da invasão por Panicum maximum Jacq. e do seu controle manual sobre a regeneração de plantas lenhosas no subbosque de um reflorestamento. Semina, 33: 97-110, 2012.

MIGUEL, E. P. et al. Floristic, structural, and allometric equations to estimate arboreal volume and biomass in a cerradão site. Semina, 38: 1691-1702, 2017.

NOMOTO, C. et al. Monitoramento das alterações da cobertura vegetal e uso do Solo na Bacia do Alto Paraguai - Porção Brasileira - Período de Análise: 2012 a 2014. Brasília: Instituto SOS Pantanal; 2015. 66 p.

PERT, P. L. et al. A catchment-based approach to mapping hydrological ecosystem services using riparian habitat: a case study from the Wet Tropics, Australia. Ecological Complexity, 7: 378-388, 2010.

RAMOS, F. T. et al. Soil organic matter doubles the cation exchange capacity of tropical soil under no-till farming in Brazil. Journal of The Science of Food and Agriculture, 98: 3595-3602, 2018.

RIBEIRO, T. O. et al. Floor quantification of fuel on the forest in the semiarid region of Paraiba, Brazil. Revista Verde, 7: 50-59, 2012.

SANTOS, H, G. et al. Sistema Brasileira de Classificação do solo. 5. ed. Brasília, DF: Embrapa Solos, 2018. 590 p.

SANTOS, R. D. et al. Manual de descrição e coleta de solo no campo. 7. ed. Viçosa, MG: Editora SBCS, 2015. $102 \mathrm{p}$.

SIMMONS, B. L. et al. Long-term outcomes of forest restoration in an urban park. Restoration Ecology, 24: 109-118, 2016.

TEIXEIRA, P. C. et al. Manual de Métodos de Análise de Solo. 3. ed. Brasília, DF: Embrapa, 2017. $573 \mathrm{p}$.

VIDRA, R. L.; SHEAR, T. H.; STUCKY, J. M. Effects of vegetation removal on native understory recovery in an exotic-rich urban forest. Journal of the Torrey Botanical Society, 134: 410-419, 2007.

WANTZEN, K. M. et al. Soil carbon stocks in stream-valley-ecosystems in the Brazilian Cerrado Agroscape. Agriculture, Ecosystems and Environment, 151: 70-79, 2012.

XIA, H. et al. Lateral heterogeneity of soil physicochemical properties in riparian after agricultural abandonment. Scientific Reports, 8: 19, 2018. 